OPEN ACCESS

Edited by:

Meghit Boumediene Khaled, University of Sidi-Bel-Abbès, Algeria

Reviewed by:

Abdullah Alkandari, Dasman Diabetes Institute, Kuwait Mustapha Diaf, University of Sidi-Bel-Abbès, Algeria

*Correspondence: Meriem Bencharif meriem.bencharif@umc.edu.dz

Specialty section:

This article was submitted to Nutrition and Metabolism, a section of the journal Frontiers in Nutrition

Received: 30 September 2021 Accepted: 12 January 2022 Published: 02 March 2022

Citation:

Bencharif M, Sersar I, Bentaleb M. Boutata FZ and Benabbas Y (2022) Ramadan Fasting and NCDs-Example of the Diabetes. Front. Nutr. 9:787571.

doi: 10.3389/fnut.2022.787571

\section{Ramadan Fasting and NCDs-Example of the Diabetes}

\author{
Meriem Bencharif ${ }^{1,2 *}$, Ibrahim Sersar ${ }^{1,3}$, Maroua Bentaleb ${ }^{1,2}$, Fatima Zohra Boutata ${ }^{4}$ and \\ Youcef Benabbas ${ }^{5}$
}

1 Institute of Nutrition, Food and Agro-Food Technologies (INATAA), University of Brother's Mentouri Constantine1 (UFMC1), Constantine, Algeria, ${ }^{2}$ Laboratory of Nutrition and Food Technology (LNTA), University of Brother's Mentouri Constantine1 (UFMC1), Constantine, Algeria, ${ }^{3}$ Laboratory of Food, Nutrition and Health (ALNUTS), University Salah Boubnider Constantine 3, Constantine, Algeria, ${ }^{4}$ Institute of Veterinary Sciences and Agronomic Sciences, Elhadj Lakhdar University, Batna, Algeria, ${ }^{5}$ Department of Internal Medicine, Hospital University, Constantine, Algeria

Although Ramadan lasts only for 1 month each year, it can be accompanied by significant changes in: both energy and nutritional intake; in the diet composition; in the working hours; and the usual way of life. The majority of practitioners consume two meals, one after sunset (Iftar) and one before dawn (Sohor). During this month, it is also an opportunity to share a meal with family and friends, a period of highly intensified socialization. In parallel with the nutritional changes brought about by this unique pattern of fasting in Ramadan, other metabolic and physiological changes may occur, such as fluctuations in body weight and/or disturbance in the quantity and quality of the sleep-wake circadian rhythm. In the verses of the Qur'an, the exemption from fasting in certain situations such as illness is clearly stated. Despite this religious tolerance, many faithful who are eligible for the exemption observe the fast of Ramadan either for the spiritual aspect it provides by performing it, by religious guilt or to mark a normalization in the Muslim community for fear of the gaze of others. The world is experiencing an increase in the emergence of non-communicable diseases (NCDs); leading cause of the global mortality. Environmental and behavioral risk factors related to lifestyle, such as smoking, excessive alcohol consumption, unhealthy diet, and sedentarity have a causal association with NCDs. Other factors, such as genetic and physiological factors may also be associated (overweight, high blood pressure, dyslipidemia). Diabetes is one of the highest prevalent NCDs in the world and it continues increasing year by year. This chronic disease can lead to significant potential complications (degenerative, dermatological, and acute) to the patient's health. This requires an individual and appropriate care, both dietetic and therapeutic and over the long term will at best make it possible to sensitize the diabetic patient to the adverse effects related to his disease and thus improve its quality of life. Performing the Fast of Ramadan for a diabetic is a common situation. Diabetes is the only chronic disease widely studied in relation to Ramadan fasting. In the literature, many studies have investigated the effects of Ramadan intermittent fasting on diabetic patients. This article aims to provide a general overview and highlight if there are many effect of Ramadan fasting on diabetes, as an example of a NCDs.

Keywords: Ramadan fasting, NCDs, diabetes, lifestyle habits, nutritional education, Muslim patient 


\section{INTRODUCTION}

Ramadan is one of the five pillars of Islam. It constitutes the month of fasting, a holy month for Muslims who have the duty to fast from sunrise to sunset. Ramadan lasts between 29 and 30 days depending on the lunar cycle, shifts from year to year and gradually changes from one season to another. This religious rite concerns all healthy Muslims in good health, and only those who are at risk of harm from fasting are exempted from this obligation such as people with non-communicable diseases (NCDs) or other disabling diseases. In the Muslim community, there is an intense desire to participate in fasting, even among those who are eligible for the religious exemption (1). Despite this, many diabetics fast despite the risk of complications and decompensation (2). Indeed, in the literature, several studies have been interested in fasting Ramadan related to diabetes as NCDs, and various works have been published on this subject around the world: in Lebanon (3), in Morocco (4), in France (5), in Tunisia (6), in Algeria $(7,8)$. The interest of this theme also lies in the fact that there are many millions of Muslims in the world and the proportion of people with diabetes who are diagnosed or not. Therefore, we have chosen in this literature review to provide a thematic overview of the problem « Ramadan and diabetes $\gg$ by exposing research and recent advances in relation to behavioral and lifestyle changes (diet, sleep, physical activity), body composition (anthropometry), metabolic changes, the link with Covid-19 pandemic and the role of nutritional education, as well as the recommendations issued on this subject.

\section{RESEARCH METHODS}

The PubMed and Google Scholar databases were searched. We also used a national online documentation system of the algerian university (SNDL.cerist). The key words used were "Ramadan fasting," "fasting" and we have associated with each of these word "diabetes," "NCDs," "circadian rhythm," "complications," "dietary habits," "physical activity," "body composition," "nutritionnal education." We mainly took the recent and most relevant studies focused on human studies. The Figure 1 summarized the studies and works included and rejected according to the literature search carried out from these three databases.

\section{EATING HABITS DURING RAMADAN}

Ramadan comes without transition, and practitioners move from one way of life to another overnight. The whole rhythm of everyday life is upset, thus reflecting a reversal of activities characterizing day and night. Normally, people eat during the day, and most socializing activities take place during the day. During Ramadan, the schedule of meals and activities is changed. These changes vary according to the seasons, geographical and socio-economic situations as well specific traditions of each country. In these conditions, the fasting body tries to adapt twice in the space of a month: at the beginning and end of Ramadan (9). The management of the diabetic patient during this month is of particular importance because of the crucial changes in lifestyle and diet both qualitatively and quantitatively.
The change in eating habits has important implications for the physiological process, such as the impact on blood glucose control. People with diabetes must maintain a healthy and balanced diet during Ramadan. However, dietary intakes are exclusively nocturnal and are most often characterized by an overconsumption of carbohydrate products and fat preparations. These dietary changes have a direct impact on the health of both fasting (DMF) and non-fasting diabetics (DMNF) (10-12). A multicenter study was carried out in 13 cities in Algeria with 2,819 type 1 (T1DM) and type 2 (T2DM) diabetics showed that DMNF approached the topic of diet with their physician more than DMF (50.6 vs. $25.9 \%$; $\mathrm{P}=0.0000$ ). Probably due to their diet during this month because, in fact, $94.6 \%$ of DMNF declared an increased consumption of carbohydrates foods, fat meals (91.6\%), higher rations $(90.5 \%)$ in the evening and heavy meals than usual (81.1\%) (13). Throughout the month of Ramadan, there is an abundance and a variety of preparations on tables and can be sold in the market level, all rich in saturated fatty acids and carbohydrates (honey cakes, pastries, traditional dishes, etc.) that are difficult to resist; a self-control for both DMF and DMNF. Moreover, in another Algerian study carried out in 276 obese women with T2DM, showed that the fast-breaking meal (Iftar) alone provided $74 \%$ of the energy intake during the month of Ramadan, which is probably not without disadvantages (glycemic variations) in diabetic patients (7). A priori in the literature research results have shown either an increase in total daily energy intake associated with an increase in the intake of carbohydrates [Tunisian prospective study, (14)], or a decrease in these intakes with an increase in the intake of carbohydrates and saturated fatty acids [Moroccan study, (15)], or no significant change in energy intake [Ajman-UEA, (16)]. The heterogeneity of the results of the various studies can be attributed to the methods of estimating dietary intake, the survey season, socioeconomic status, and other lifestyle variations of the different populations studied.

\section{CHANGE IN THE NYCTHEMERAL CYCLE}

Food deprivation, in general, is deemed to have an influence on a number of physiological functions (17). According to Khalfallah et al. (18), chronobiological inversion of nutritional habit is responsible of several functional disorders. Ramadan is a chronobiological desynchronization model which is characterized by a reversal of the foodboorne and waterboorne rhythm. The fasting of Ramadan has the particularity of constantly changing the synchronizers of the central clocks for a month. On healthy volunteers, a comparative study was carried out under identical observation conditions (Winter Ramadan and summer Ramadan). Researchers found that sleep debt could accumulate without compensation through daytime naps and that Ramadan alters the circadian organization of the sleep-wake rhythm, and this, most importantly, in summer when the photoperiod is the longest (19). Sleep can appear simply as a state of rest. It, nevertheless, constitutes a complex physiological state, necessary for the survival of the organism, characterized by different phases of deep sleep (20). The rhythm of life imposed by 


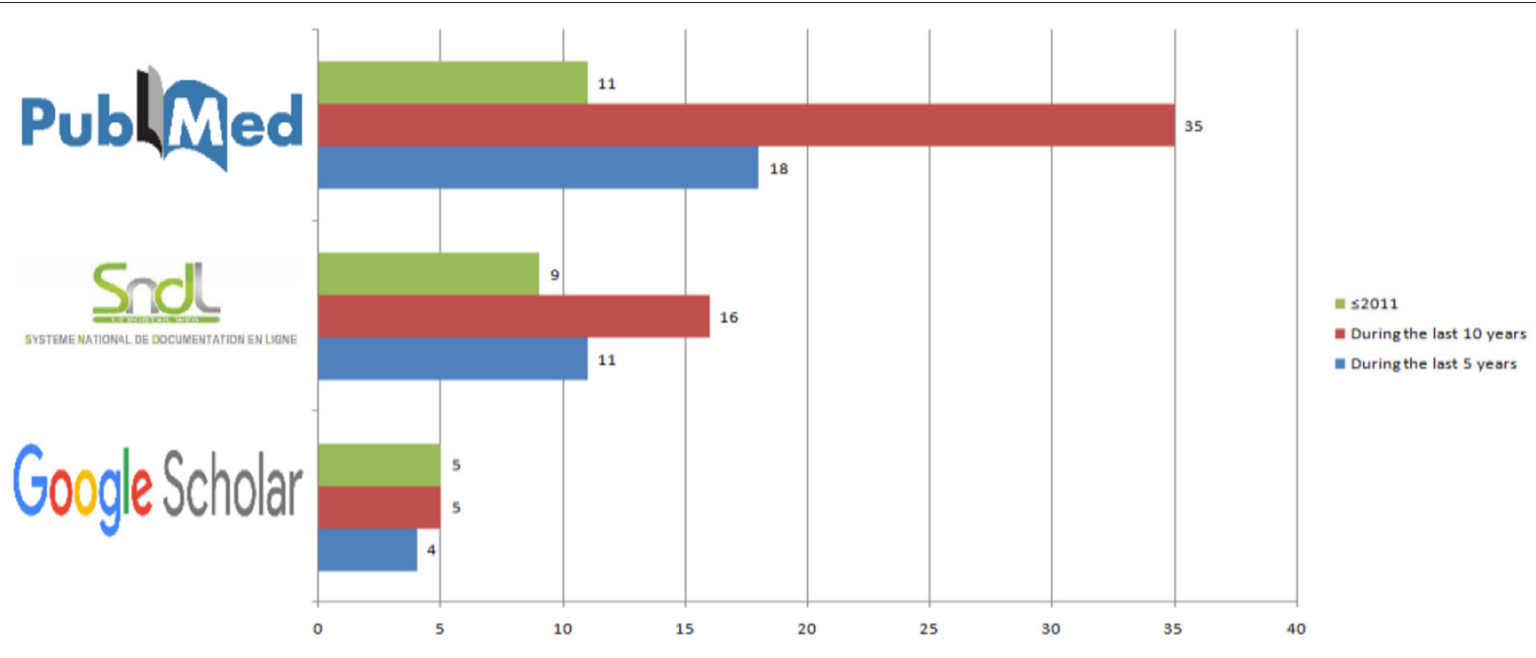

Studies included

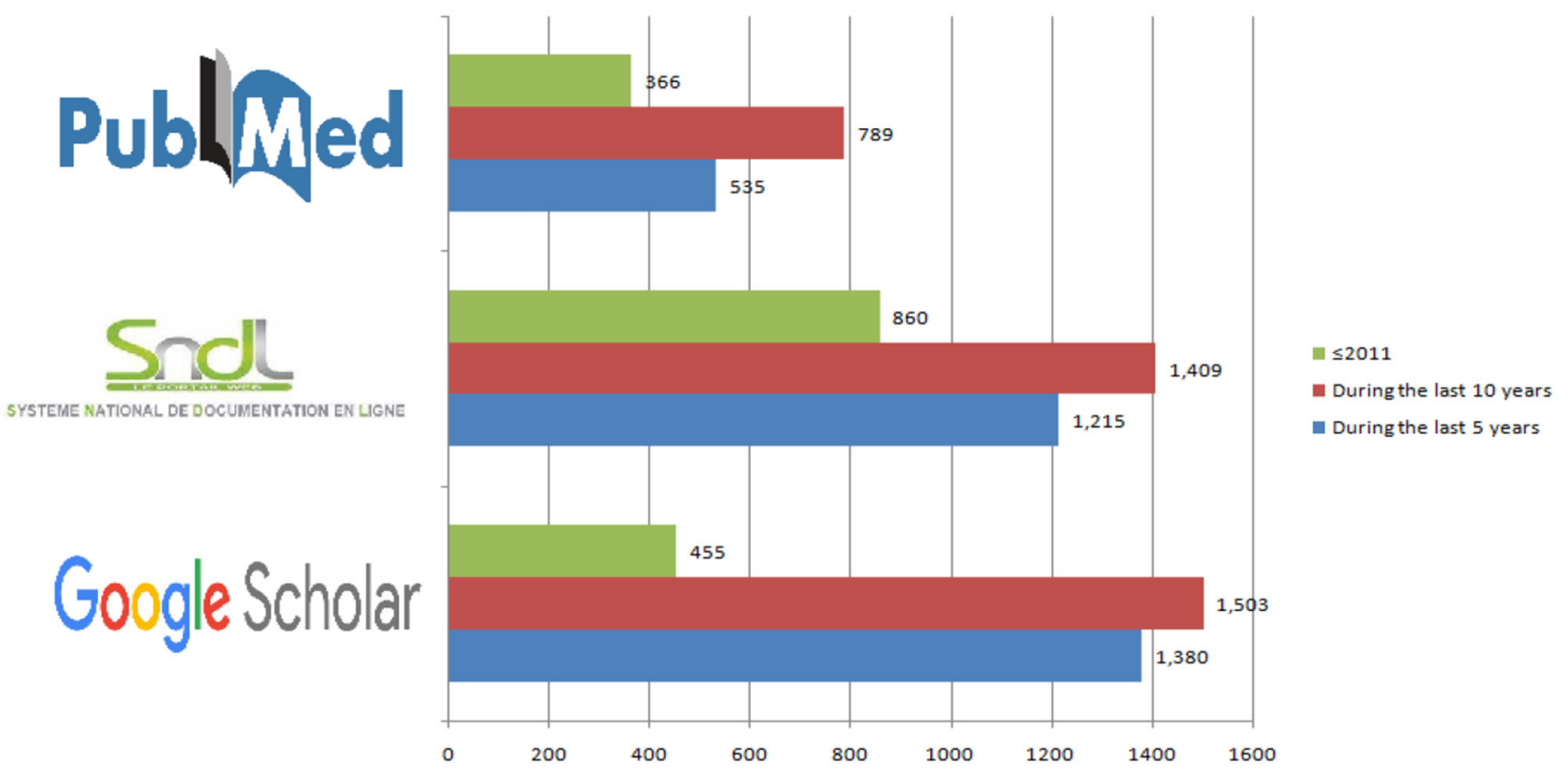

Studies rejected

FIGURE 1 | Studies included and rejected according to the literature search.

the month of Ramadan systematically leads to a decrease in the duration in sleep time. In a study of 2,708 diabetics (21), a sleepwake cycle disturbance was observed, where sleep decreased during the month of Ramadan, while napping increased $(p<$ 0.05 ). The results of another study carried out on 1,266 diabetic patients showed an average sleep duration between 5 to $8 \mathrm{~h}$ in $70.3 \%$ of T2DM and $65.5 \%$ of T1DM. The same results both for the DMF and DMNF (22). In an epidemiological study related to the sleep-wake rhythm during Ramadan, researchers found a significant increase in sleep latency, intra sleep warkining and daytime naps. These disturbances appeared from the first week of fasting, persisted throughout the month, and disappeared after the post-Ramadan period. This sleep-wake rhythm disturbances also persisted on weekends (23). 


\section{PHYSICAL ACTIVITY PRACTICE}

Physical activity can help people with diabetes achieve a variety of goals, like improving their cardiorespiratory health; increasing their physical endurance; better controlling their blood glucose levels; reducing their insulin resistance; improving their lipid profile; lowering their blood pressure; and maintaining weight loss (24). Sedentary lifestyle in an individual can increase the risk of early mortality (25). In patients with T2DM, regular physical activity reduces the risk of all-cause mortality (between -30 and $-40 \%)$, as well as cardiovascular mortality ( -25 to $-40 \%)(26)$. Indeed, the study of Kooiman et al. (27) in people with T2DM, showed an increase in the physical activity that was correlated with decreased levels of glycated haemoglobin (HbAlc) and blood glucose and decreased cardiovascular complications. The continuation of religious practices, as well as the disturbances of the circadian rhythm that are associated with the fasting of Ramadan, such as the perceived feeling of subjective fatigue, drowsiness, thirst and/or even mood swings, can lead to a significant decrease in the level of physical activity of Muslims (28). Results from a Moroccan study on healthy athletic adults showed a significant reduction in physical performance and a significant effect of Ramadan fasting on blood glucose and memory (29). Paradoxically, the results of a study on Algerian basketball players from a sports club showed no variations in training during the month of Ramadan and no significant effect on sports activity (30). According to Ghrici (31), the practice of moderate sport promotes physiological adaptation to fasting, since some changes during Ramadan are observed in sedentary people and not in athletes. This is the case with variations in blood glucose and triglycerides. Studies of substitution of sedentary time by physical activity (iso-temporal substitution) confirm the importance of replacing this sedentary time with physical activity, regardless of its intensity (25). During the month of Ramadan, physical activity levels must be maintained, whether for the general population or the sick population such as diabetics, but this is not always the case. In a study of Saudi diabetics, a high prevalence of physical inactivity and an increase in sedentary time were shown during Ramadan (32). While the work of Sfar et al. (33) showed a non-significant increase in physical activity in Tunisians with T2DM during Ramadan compared to the pre-Ramadan period. With longer intervals between the two main meals of the day, there can be a reduction in physical activity and exercise during the day (34). During a summer Ramadan, as in recent years, it is difficult to get around in the heat wave all day except to go to work and shopping in the market. Only the movement to the mosque to fulfill the voluntary evening prayers made in groups during the holy month of Ramadan 《Tarawih 》 and/or social gatherings between family and friends allow to maintain a minimum level of daily physical activity throughout the month of Ramadan. Being physically active during Ramadan can help the individual to maintain his/her level of conditioning, as well as better deal with intermittent fast (28). However, excessive physical activity can increase the risk of hypoglycemia and hence should be avoided (10).

\section{BODY COMPOSITION}

The diet during the holy month of Ramadan should be the same as throughout the year, that is, a healthy and balanced diet from qualitative and quantitative perspectives. It should aim to maintain a constant body mass. In the meta-analysis of Tahapary et al. (35), on the impact of Ramadan fasting on the metabolic profile in the $2 \mathrm{TDM}$ patients, a change was found in body weight in 15 studies with 2,511 patients. Overall, there was a slight overall reduction in body weight of $0.71 \mathrm{~kg}$ (CI at $95 \%-.45-0.003 \mathrm{~kg})$. Similarly, six studies involving 2,289 T2DM subjects reported a decrease in waist circumference of $0.62 \mathrm{~cm}$ (CI at 95\%-1.31$0.08 \mathrm{~cm}$ ) before and after the fast of Ramadan. As for the effect of Ramadan fasting on the body composition of the diabetic patient, the results were discordant. The researchers Aloulou et al. (36), Khaled and Belbraouet (7), and McEwen et al. (37) reported changes, in other studies some changes were found $(16,38,39)$ and for others no change was found $(6,21,40-43)$.

\section{FASTING, METABOLIC CHANGES, COMPLICATIONS, AND CLINICAL ASPECTS}

Fasting induces a secondary adaptive metabolic cascade to hormonal changes. The challenge is to make the best use of stored energy substrates during feeding periods, by keeping blood glucose levels as low as possible in the normal range, while preserving the protein capital (44). Metabolic adaptation to fast is designed to spare fat free mass (mainly muscle mass) or active cell mass. At the initial phase of fasting and in normal conditions, the body mobilizes fat reserves which are oxidized into ketone bodies then used by the brain; at this point, neo-glucogenesis of protein origin is reduced, allowing some saving of the freefat mass (45). In the case of diabetes, lack of insulin promotes metabolism to ketone body production, which can cause diabetic ketoacidosis. This situation is compounded by difficulties in adjusting therapeutic doses during this month of fasting, which is not without consequence. Indeed, in T1DM there is no endogenous production of insulin by the pancreas. Therefore, insulin intake is entirely dependent on injections. While in the T2DM, endogenous insulin is still secreted, but inadequately or inappropriately, and glucagon is preponderante (46). During Ramadan, fasting-related complications for diabetics can include hyperglycemia, hypoglycemia, acidoketosis, dehydration, or thrombosis $(2,21,47-51)$. These consequences are subject in most cases to hospitalization and complete interruption of fasting until the end of the holy month of Ramadan. In the literature, the variation of certain biochemical and clinical parameters, significant or not, contradicted, has been reported in relation to the effect of fasting in diabetics. The study results of Ouhdouch et al. (52) and of Abdessadek et al. (53) reported a significant decrease in $\mathrm{HbAlc}$, while the opposite was noted in the study of Halimi et al. (54) and of Mbainguinam et al. (55) explaining this inequality of $\mathrm{HbAlc}$ would be the cause of hypertriglyceridemia. Also, an improvement in the lipid profile $(53,56,57)$ was found, a significant decrease in fasting blood glucose during Ramadan 
compared to outside $(53,57,58)$, hyperglycaemic episodes with or without ketoacidosis and severe hypoglycaemia (59-61), the presence of higher hypoglycemia in patients treated with insulin ( $p=0.002)$, followed by those treated with oral agents including sulfonylureas as compared to oral agents excluding sulfonylureas (57). Also saved, a non-significant reduction in plasma creatinine, uric acid (53), an improvement in blood pressure figures (57), while in another study no change was found $(6,56)$.

\section{COVID-19 PANDEMIC, DIABETES, AND RAMADAN FASTING}

As for last year, Ramadan fasting took place in a particular context; in the midst of the COVID-19 pandemic. According to international iterim guidelines (62), healthy people should be able to fast during Ramadan, as in previous years, While COVID19 patients should consider not doing so, following religious exemptions, in consultation with their physician, as with any other illness. According to Khan et al. (63), fasting during the COVID-19 crisis was a challenge for diabetic Muslims during Ramadan. A study of 829 diabetics, 34 fasting patients developed symptoms of COVID-19 before or during Ramadan. Ten patients (four fasters and six non-fasters) were admitted with symptoms related to COVID-19 (nine of whom were confirmed COVID19 positive), however, none required intensive care. In the study of the DAR 2020 global survey on Ramadan fasting during the COVID-19 pandemic aiming to describe the characteristics and care of participants with T2DM showed that in 5,865 participants (recruited from 20 predominantly Muslim cities) concern over the COVID-19 pandemic affected the decision to fast by $7.6 \%$ from $\geq 65$ years old vs. $5.4 \%$ from $<65$ years old, while $94.8 \%$ fasted $\geq 15$ days and $12.6 \%$ had to break the fast due to diabetesrelated illness (64). As reported by Chowdhury et al. (65), if a diabetic develops symptoms of COVID-19 during fasting, he/she must be told to break the fast immediately, to hydrate, to regularly monitor capillary blood glucose, because according to the study of $\mathrm{Li}$ et al. (66), there is evidence that ketosis and ketoacidosis were more common in people with diabetes and COVID19. In their article Chowdhury et al. (65) continued that this applies particularly to patients on sodium-glucose 2 transporter inhibitors (SGLT2i) (67). If a patient is not feeling well with symptoms of COVID-19, it may require hospitalization as it is at high risk of deterioration. There are guidelines suggesting that metformin and SGLT2i should be discontinued in all diabetic and suspected COVID-19 patients requiring hospitalization $(65,68)$.

\section{NUTRITIONAL EDUCATION}

Ramadan is a special time in the life of Muslim diabetic patients leading to a major and sudden change in their rhythm of life having an impact on the management of their diabetes $(69,70)$. In a study highlighting the point of view of health professionals on the difficulties encountered during medical consultations during Ramadan, it was noted: treatment management (69.1\%), glycaemic variations $(52.1 \%)$, venous thrombosis (8.8\%), weight gain $(2.8 \%)$, changes in eating habits $(42.9 \%)$ and food intake schedules (50.7\%). The results of this study also showed that out of 1,975 diabetic patients, 924 of them did not know about the conditions for interruption of fasting whether T1DM or T2DM (53.0 vs. $46.4 \% ; p=0.2984$ ) (13). In parallel, in another study highlighting the role of nutritional education in the management of T2DM during Ramadan, the researchers showed that $96 \%$ of the patients who received educational sessions were able to fast more than 21 days with a frequency of hypoglycemia 9 times lower compared to the control group (71). The patient wishing to fast must also be followed nutritionally; pair a balanced and varied diet (coverage of recommended nutritional intakes and respect for food preferences), appropriate treatment (in molecule, dose and frequency of intake), added to glycaemic control, will allow the diabetic patient to better manage his/her disease (13, 69, 70). Pre-Ramadan education is crucial to fast safely during the holy month. Education on fasting and diabetes management is also useful beyond Ramadan (72) having regard to the number of fasters after Ramadan [Example: CREED study (73) between 8 and 46\%] and its important place in Muslim society. Admittedly, it is not an obligation, but an accomplishment of a pious act and an inner comfort that can be achieved throughout the year, but also the possibility and not the obligation (especially for the sick patients) to catch up for the unfasted days of the month of Ramadan (13).

\section{ESSENTIALS POINTS IN TERM FOR RECOMMENDATIONS}

Several international recommendations and consensus of experts have resulted in proposals to optimize diabetes management during the month of Ramadan:

- The first international recommendations for a good practice of fasting were those of the Hassan II Foundation in Morocco in 1995. This consensus proposed criteria authorizing and prohibiting fasting and reinforced clinical-biological surveillance before, during and after Ramadan, a monitoring of glycemic control, adaptation of treatment, education of diabetics, and their families on the contraindications of fasting, the risk of acute complications and the means of prevention and treatment (74).

- Other recommendations follow those of Morocco, including those of the American Diabetes Association (ADA) published in 2005 (75). In these recommendations, the term "indications" or "counter-indications" of fasting was avoided because the authors considered Ramadan fasting to be a spiritual religious issue for which patients make their own decisions after receiving appropriate advice from religious teachings and their own health professionals. In response to numerous requests and comments on important issues that were not discussed in the previous 2005 document, these recommendations were subsequently revised by regular updates every 5 years and were also the subject of other publications.

- In 2010 (76), research highlighted once again that fast in T1DM patients with poor glycemic control is associated with multiple risks. In the revised document, some issues were 
discussed, concerning voluntary fasting outside Ramadan, discussion of the effect of prolonged fasting (more than $18 \mathrm{~h}$ per day) in remote areas of the equator during Ramadan when it occurs in summer, on the lower risk of hypoglycaemia, such as incretin based therapies and, on the limits of drugs and their use as thiazolidinediones.

- The third update to the recommendations of the ADA Working Group (77) was also published following numerous requests for information on education, dietary habits and new oral and injectable agents that may be useful for the management of diabetic patients during Ramadan.

- In the 2020 update (78), the research group aimed to apply the principles of ADA/European Association for the Study of Diabetes (EASD) type 2 diabetes management guidelines to Ramadan. New sections on the management of T1DM children and gestational diabetes were included. They carefully reviewed the literature and published data on medical nutrition therapy and the use of oral diabetes medication during Ramadan.

- The International Diabetes Federation (IDF) and the Diabetes and Ramadan (DAR) International Alliance met to provide comprehensive guidance on this topic. This guide (79) highlights relevant contextual information and practical recommendations to help diabetic patients to fast during Ramadan while minimizing the risk of complications. The guidelines cover several key topics, including epidemiology, physiology of fasting, risk stratification, nutritional advice, medication adjustment, and implementation of recommendations. One of the recurring themes in the guidelines is the importance of individualization and education as part of a diabetes management plan.

- The update of the IDF-DAR International Alliance Practical Guidelines features new guidance based on a greater and more recent body of evidence (80). This includes an updated set of criteria for risk stratification; information on the impact of fasting on physical and mental wellbeing; specific guidance on the management of T1DM and T2DM in special populations such as pregnant women and the elderly; and information on changes to the risk of comorbidities such as cardiovascular disease, stroke, and renal impairment.

- In addition, the Asian recommendations of the South Asian Consensus Guideline, where researchers (81) indicate that it is possible for people with diabetes to fast safely during Ramadan, but requires careful planning in order to avoid

\section{REFERENCES}

1. Hassanein M, Al-Arouj M, Hamdy O, Wan-Bebakar WM, Jabbar A, AlMadani A, et al. Diabetes and Ramadan: pratical guidelines. Diabetes Res Clin Pract. (2017) 126:303-16. doi: 10.1016/j.diabres.2017.03.003

2. Héliniak E, Chambin O, Sari H, Michiels Y, Pillon F. Diabète et Ramadan, une pratique à risque. Actualités Pharmaceutiques. (2015) 54:48-52. doi: 10.1016/j.actpha.2015.03.035

3. Beshyah SA, Benbarka MM, Sherif IH. Practical management of diabetes during Ramadan fast. Libyan J Med. (2007) 2:185-9. doi: $10.3402 /$ ljm.v2i4.4731 problems that could be serious and have long-term effects. The choice of insulin therapy is decided by the previous therapy that the patient is taking and also the blood glucose profiles. The major objective of insulin therapy during Ramadan is to provide adequate insulin to prevent the post meal (After Iftar) hyperglycemia and also prevent hypoglycaemia during the period of fast. With the use of analoges, these objectives may be met more easily.

The importance of the socio-cultural context of the holy month of Ramadan associated with the culturally-religious identity to which the diabetic patient is or wants to adhere are parameters to be included in the decision to fast. The advice of health professionals and members of religion will only reassure the diabetic in the accuracy of their decision. Each patient must be monitored individually, taking into account in particular the evolution of his disease, his therapeutic treatment, his socio-economic level, his level of education, his age, and his family status.

\section{CONCLUSION}

Fasting is a very sensitive period for the glycemic control of DMF and DMNF patients, requiring multidisciplinary preparation and expert advice. This work gave a brief visualization of the effect of Ramadan fasting on a NCDs which is diabetes. The few studies cited reflecting the various points raised (diet, sleep, physical activity, body composition, metabolic changes, nutrition education) showed heterogeneity of the results found probably due to the number of days of fasting, climatic conditions, cultural variations in eating habits, etc. Some slight advantages were noted. These particularities must be taken into account in the development of any study project on this topic. Effective management of diabetes with regular glycemic control will allow the patient to maintain an appropriate metabolic profile. Education on fasting and diabetes management is useful beyond Ramadan. It is important that recommendations have to be based on the gaps in existing data.

\section{AUTHOR CONTRIBUTIONS}

MBenc: study design, literature searching, and article draft writing. IS, MBent, and FB: draft revision and literature searching. YB: draft revision. All authors agree to be accountable for the content of the work. pour les patients diabétiques et les soignants. Sciences Sociales et Santé. (2008) 26:79-104. doi: 10.3917/sss.262.0079

5. Gaborit B, Duthur O, Ronsin O, Atlan C, Darmon P, Gharsalli R. Ramadan fasting with diabetes: an interview study of inpatients' and general attitudes in the South of France. Diabetes \& Metab. (2011) 37:395-402. doi: 10.1016/j.diabet.2010.12.010

6. Bouguerra R, Belkadhi A, Jabrane J, Hamzaoui J, Maâtki C, Ben Rayana MC, et al. Metabolic effects of Ramadan fasting on type 2 diabetes. EMHJ. (2003) 9:1099-108. doi: 10.26719/2003.9.5-6. 1099 
7. Khaled MB, Belbraouet S. Effect of Ramadan fasting on anthropometric parameters and food consumption in 276 type 2 diabetic obese women. Int J Diabetes Dev Ctries. (2009) 29:62-8. doi: 10.4103/0973-3930.53122

8. Bencharif M, Sersar I, Bentaleb M, Boutata FZ, Benabbas Y. Highlighted of Ramadan fasting on diabetes-study of complications, biochemical aspects and anthropometry. Rom J Diabetes Nutr Metab Dis. (2019) 24:227-34. doi: 10.2478/rjdnmd-2019-0023

9. Gundesli Dagtekin S. Ramadan et diabète. Thèse pour obtenir le grade de Docteur en Médecine, Faculté de médecine de Nancy, Nancy: Université Henry Poincaré (2008) 1. 144p.

10. Ibrahim AI. Gérer le diabète pendant le Ramadan. Diabetes Voice. (2007) 52:19-22. Available online at: https://diabetesvoice.org/fr/

11. Sebbani M, El Ansari N, El Mghari G, Amine M. Food intake during the month of Ramadan in Moroccan patients with type 2 diabetes. EMHJ. (2013) 19:276-81. doi: 10.26719/2013.19.3.276

12. Bencharif M, Fenaghra A, Boudaoud C, Hadji NE, Benyaya H, Benabbas Y. Impact of Ramadan fasting on energy intake and anthropometry of type 2 diabetics-Study in two regions of the central highlands and southeastern Algeria. J Fast Health. (2017) 5:31-7.

13. Bencharif M, Sersar I, Candau J, Jeanjean A, Benabbas Y. Ramadan et diabète: attitudes des patients versus points de vue des médecins, religieux, et membres d'associations. Med Mal Metab. (2020) 14:258-68. doi: 10.1016/j.mmm.2020.03.007

14. Khadraoui E, Fendi O, Temessek A, Mouelhi A, Ben Mami F. Alimentation des patients diabétiques pendant le mois de Ramadan. Annales d'Endocrinologie. (2012) 73:387. doi: 10.1016/j.ando.2012.07.945

15. Baki S, El Mghari G, El Ansari N. Évaluation de l'apport nutritionnel chez les praticiens des urgences au cours de Ramadan. Nutr Clin Metab. (2014) 28:S84. doi: 10.1016/S0985-0562(14)70674-0

16. Sadiya A, Ahmed S, Siddieg HH, Babas IJ, Carlsson M. Effect of Ramadan fasting on metabolic markers, body composition, and dietary intake in Emiratis of Ajman (UAE) with metabolic syndrome. Diabetes Metab Syndr Obes. (2011) 4:409-16. doi: 10.2147/DMSO.S24221

17. El Moutawakil B, Hassounr S, Sibai M, Rafai MA, Fabrigoule C, Slassi I. Impact du jeûne du Ramadan sur les fonctions attentionnelles. Rev Neurol. (2007) 163:60. doi: 10.1016/S0035-3787(07)90595-0

18. Khalfallah T, Chaari N, Henchi MA, Abdallah B, Ben Chikh R, Saafi MA, et al. Evaluation of the impact of Ramadan fast on the physical workload. Archives des Maladies Professionnelles et de l'Environnement. (2004) 65:56470. doi: 10.1016/S1775-8785(04)93519-9

19. Davenne D, Berrichi H, Taibi A, Bessot N. Comparaison des rythmes veille-sommeil recueillis lors du suivi du jeûne pendant un Ramadan hivernal et un Ramadan estival. Médecin Du Travail. (2018) 15:46. doi: 10.1016/j.msom.2018.01.123

20. Challet E. Sommeil et nutrition: approche chronobiologique par les rythmes hormonaux. Cah Nutr Diet. (2005) 40:137-41. doi: 10.1016/S0007-9960(05)80478-X

21. Bencharif M. Etude multicentrique des effets du jeûne du Ramadan chez une population de diabétiques (2013). Thèse de doctorat, INATAA, UFMC1 2017. 210p

22. Elleuch M, Hana C, Boujelben K, Ben Salah D, Hadj Kacem F, Mnif $\mathrm{M}$, et al. L'alimentation du diabétique pendant le mois de Ramadan en Tunisie. La Revue de médecine interne. (2020) 47(Suppl): A.111-2. doi: 10.1016/j.revmed.2020.10.186

23. Berrichi H, Taibi A, Davenne D. Rythme veille-sommeil au cours du Ramadan. Neurophysiologie Clinique. (2013) 43:146. doi: 10.1016/j.neucli.2013. 01.064

24. Sigal RJ, Armstrong MJ, Colby P, Kenny GP, Plotnikoff RC, Reichert SM, et al. Activité physique et diabète. Can J Diabetes. (2013) 35:S403-8. doi: 10.1016/j.jcjd.2013.07.047

25. Duclos M. Épidémiologie et effets sur la morbi-mortalité de l'activité physique et de la sédentarité dans la population générale. Revue du Rhumatisme Monographies. (2021) 88:177-82. doi: 10.1016/j.monrhu.2020.11.008

26. INSERM. Activité physique: prévention et traitement des maladies chroniques. Paris: EDP Sciences (2019). 124p.

27. Kooiman TJM, de Groot M, Hoogenberg K, Krijnen WP, van der Schans CP, Kooy A. Self-tracking of Physical Activity in People With Type 2 Diabetes. A Randomized Controlled Trial Cin Computers Inform Nursing. (2018) 36:340-9. doi: 10.1097/CIN.0000000000000443
28. Alkandari JR, Maughan RJ, Roky R, Aziz AR, Karli U. The implications of Ramadan fasting for human health and well-being. J Sports Sci. (2012) 30:S9-S19. doi: 10.1080/02640414.2012.698298

29. Lotfi S, Madani M, Tazi A, Boumahmaza M, Talbi M. Variation des fonctions cognitives et de la glycémie lors de l'exercice physique durant le jeûne du mois de Ramadan. Rev Neurol. (2010) 166:721-6. doi: 10.1016/j.neurol.2010.01.016

30. Bencharif M, Sersar I, Zerdoumi B, Benabbas Y. The impact of ramadan fasting on the sports activities, diet, and anthropometry of basketball players in Eastern Algeria. J Nutr Fast Health. (2021) 9:23-8. doi: $10.22038 /$ jnfh.2020.43886.1231

31. Ghrici H. Linfluence du jeûne et du rythme biologique sur l'organisme humain. Thèse de doctorat, Institut d'éducation physique et sportive, Algérie: Université Mostaganem (2019). 128p.

32. Alghamdi AS, Alghamdi KA, Jenkins RO, Alghamdi MN, Haris PI. Impact of Ramadan on physical activity and sleeping patterns in individuals with type 2 diabetes: the first study using fitbit device. Diabetes Ther. (2020) 11:1331-46. doi: 10.1007/s13300-020-00825-x

33. Sfar H, Sellami S, Boukhayatia F, Ben Naceur K, Ben Mami F. Biochemical, physiological and body composition changes in patients with type 2 diabetes during Ramadan fasting. IJMBS. (2017) 9:164-8. doi: 10.4103/ijmbs.ijmbs_59_17

34. Lessan N, Saadane I, Alkaf B, Hambly C, Buckley AJ, Finer N, et al. The effects of Ramadan fasting on activity and energy expenditure. Am J Clin Nutr. (2018) 107:54-61. doi: 10.1093/ajcn/nqx016

35. Tahapary DL, Astrella C, Kristanti M, Harbuwono DS, Soewondo P. The impact of Ramadan fasting on metabolic profile among type 2 diabetes mellitus patients: a meta-analysis. Diabetes Metab Syndr: Clinical Res \& Reviews. (2020) 14:1559-70. doi: 10.1016/j.dsx.2020.07.033

36. Aloulou I, Masmoudi K, Zouari N. Habitudes alimentaires au cours du jeûne du mois de Ramadan et effets sur la composition corporelle et l'insulino-sensibilité. Ann Endocrinol. (2005) 66:408. doi: 10.1016/S0003-4266(05)81849-9

37. McEwen LN, Ibrahim M, Ali NM, Assaad-Khalil SH, Tantawi G, Nasr G et al. mpact of an individualized type 2 diabetes education program on clinical outcomes during Ramadan. BMJ Open Diab Res Care. (2015) 3:1-8. doi: 10.1136/bmjdrc-2015-000111

38. Traoré M, Lemieux S, Galibois I. Profils métabolique et clinique avant, pendant et après la période du ramadan chez des Maliens atteints de diabète de type 2. Nutr Clin Metab. (2014) 28:83-9. doi: 10.1016/j.nupar.2013.12.006

39. Osman F, Haldar S, Henry CJ. Effects of time-restricted feeding during Ramadan on dietary intake, body composition and metabolic outcomes. Nutrients. (2020) 12:1-25. doi: 10.3390/nu12082478

40. El-Ati J, Bejie C, Danguir J. Increased fat oxydation during Ramadan fasting in healthy women: an adaptative mechanism for body-weight maintenance. Am J Clin Nutr. (1995) 62:302-7. doi: 10.1093/ajcn/62.2.302

41. Uysal AR, Erdogan MF, Sahin G, Kamel N, Erdogan G. Clinical and Metabolic Effects of Fasting in 41 Type 2 Diabetic Patients During Ramadan. Diabetes Care. (1998) 21:2033-4. doi: 10.2337/diacare.21.11.2033

42. Beltaifa L, Bouguerra R, Ben Slama C, Jabrane H, El-Khadhi A, Ben Rayana $\mathrm{MC}$ et al. Apports alimentaires, paramètres anthropométriques et biologiques chez des sujets adultes tunisiens au cours du jeûne de Ramadan. EMHJ. (2002) 8: 603-11. doi: 10.26719/2002.8.4-5.603

43. Ait Saada D, Selselet Attou G, Mouhtadi F, Kassoul S, Italhi M, Kati D. Effect of the Ramadan Fasting on the Variations of Certain Anthropometric and Biochemical Parameters in Type 2 Diabetic Patients Treated with Medications Mixture (Biguanides and Sulfamides). Advan Biol Res. (2008) 2:111-20. Available online at: https://www.ajol.info/index.php/ajb/article/view/77772

44. Schlienger JL. Does the fast have a medical interest? Med Mal Metab. (2015) 9:681-6. doi: 10.1016/S1957-2557(15)30245-5

45. Zazzo JF. Mécanismes et conséquences de la dénutrition. Rev Prat. (2003) 53:248-53. Available online at: https://solidarites-sante.gouv.fr/IMG/ pdf/brochure_denutrition.pdf

46. Zantar A, Azzoug S, Belhimer F, Chentli F. Diabète et Ramadan. Presse Med. (2012) 41:1084-8. doi: 10.1016/j.lpm.2012.07.012

47. El Aassri H, El Mehgari G, El Ansari N. État des lieux des urgences diabétologiques durant le mois de Ramadan. Diabetes Metab. (2011) 37: A60. doi: 10.1016/S1262-3636(11)70731-5

48. Faraoun K, Ayad N, Daoud M, Melouah S, Mohammedi F. Profil des patients diabétiques vus en urgence pendant le mois de Ramadan 
à la clinique Laribere, CHU Oran. Diabetes Metab. (2014) 40:A57. doi: 10.1016/S1262-3636(14)72411-5

49. Bessemans S, Paquot N. Diabète et Ramadan. Rev Med Liege. (2017) 72:1-5. Available online at: http://hdl.handle.net/2268/219451

50. Deeb A. Al Qahtani, NAkle M, Singhb H, Assadi R, Attia S. Attitude, complications, ability of fasting and glycemic control in fasting ramadan by children and adolescents with type 1 diabetes mellitus. Diabetes Res Clin Prac. (2017) 127:10-5. doi: 10.1016/j.diabres.2017.01.015

51. Bammou S, Ekoundzola R, Rafi S, El Mghari G, El Ansari N. Impact du jeûne sur la survenue des hypoglycémies et hyperglycémies au cours du mois de Ramadan. Int J Adv Res. (2021) 9:739-42. doi: 10.21474/IJAR01/ 13070

52. Ouhdouch F, Adarmouch L, Errajraji A, Amine M, El-Ansari N. Absence d'effets délétères du jeûne du Ramadan sur l'équilibre glycémique chez des patients diabétiques: rôle des consultations de préparation au jeune. Med Mal Metab. (2011) 5:448-52. doi: 10.1016/S1957-2557(11)70289-9

53. Abdessadek M, Khabbal Y, Magoul R, Marmouzi I, Ajdi F. Follow-up of glycemic index before and after Ramadan fasting in type 2 diabetes patients under antidiabetic medications. Annales Pharmaceutiques Françaises. (2019) 77:374-81. doi: 10.1016/j.pharma.2019.04.003

54. Halimi S, Lévy M, Amghar H. Cas clinique: croyances, Ramadan et Diabète. Ann. Endocrinol. (2004) 65(Suppl.1): 1S68-1S73. doi: 10.1016/S0003-4266(04)96003-9

55. Mbainguinam D, Tidjani A, Hassan AH. Impact du jeûne de Ramadan sur le profil métabolique du diabétique de type 2 suivi en consultation spécialisée à N’Djamena. Diabetes Metab. (2015) 41:A91. doi: 10.1016/S1262-3636(15)30343-8

56. Benmoussa S. Ramadan chez le diabétique de type 2. Annales d'Endocrinologie. (2016) 77:507. doi: 10.1016/j.ando.2016.07.773

57. Ismail A, Meglaa MH, Badrah M, Farghaly M. Study of the metabolic effects of Ramadan fasting on patients with type 2 diabetes. Relation to Glycemic Cont, Hypoglycemic Eve and Diabetic Compl Clin Diabetology. (2021) 10:161-8. doi: 10.5603/DK.a2020.0004

58. Bah A, Baldé NM, Barry TO, Diakite M, Bangoura JS, Dieng $\mathrm{K}$ et al. Diabète et jeûne du Ramadan: Aspect clinique et évolutif au service de diabétologie de Donka. Diabetes Res Clin Pract. (2014) 103S: 124. doi: 10.1016/S0168-8227(14)70078-6

59. Salti I, Benard E, Detournay B, Bianchi-Biscay M, Le Brigand C, Voinet C, et al. A population-based study of diabetes and its characteristics during the fasting month of Ramadan in 13 countries: results of the epidemiology of diabetes and Ramadan 1422/2001 (EPIDIAR) study. Diabetes Care. (2004) 27:2306-11. doi: $10.2337 /$ diacare.27.10.2306

60. Hassanein M, Al Awadi FF, El Sayed El Hadidy K, Alic SS, Echtay A, Djaballah K. The characteristics and pattern of care for the type 2 diabetes mellitus population in the MENA region during Ramadan: an international prospective study (DAR-MENA T2DM). Diabetes Res Clin Pract. (2019) 151:275-84. doi: 10.1016/j.diabres.2019.02.020

61. Malek R, Hannat S, Nechadi A, Mekideche FZ, Kaabeche M. Diabetes and Ramadan: a multicenter study in Algerian population. Diabetes Res Clin Pract. (2019) 150:322-30. doi: 10.1016/j.diabres.2019.02.008

62. World Health Organization (WHO). Safe Ramadan practices in the context of the COVID-19 (2020). 3p. Available online at: https://apps.who.int/iris/ handle/10665/331767 (accessed March 31, 2021).

63. Khan H, ChowdhuryA, Lasker SS, Chowdhury TA. The effect of COVID19 on Ramadan fasting in people with diabetes in East London 2020: The East London diabetes in Ramadan survey. Diabetes Res. Clin. Pract. (2020) 169: 108476-79. doi: 10.1016/j.diabres.2020.108476

64. Hassanein M, Hussein Z, Shaltout I, Seman WJW, Voon TC, Noor NM, et al. The DAR 2020 global survey: Ramadan fasting during COVID 19 pandemic and the impact of older age on fasting among adults with Type 2 diabetes. Diabetes Res Clin Pract. (2021) 173:108674-84. doi: 10.1016/j.diabres.2021.108674

65. Chowdhury TA, Waqar S, Hussain S, Ahmed SH, Syed A, Karamat A, et al. COVID-19, Diabetes and Ramadan. Diabetes Ther. (2020) 11:2447-51. doi: 10.1007/s13300-020-00887-x

66. Li J, Wang X, Chen J, ZuoX, Zhang H, Deng A. COVID-19 infection may cause ketosis and ketoacidosis Diabetes Obes Metab. (2020) 22:1935-41. doi: 10.1111/dom.14057

67. Liu J, Li L, Li S, Wang Y, Qin X, Deng K, et al. Sodium-glucose co-transporter2 inhibitors and the risk of diabetic ketoacidosis in patients with type 2 diabetes: a systematic review and meta-analysis of randomized controlled trials. Diabetes Obes Metab. (2020) 22:1619-27. doi: 10.1111/dom.14075

68. Hanif S, Ali SN, Hassanein M, Khunti K, Hanif W. Managing people with diabetes fasting for Ramadan during the COVID-19 pandemic: a South Asian health foundation update. Diabet Med. (2020) 37:1094-102. doi: $10.1111 /$ dme.14312

69. Hui E, Bravis V, Hassanein M, Hanif W, Malik R, Chowdhury TA, et al. Management of people with diabetes wanting to fast during Ramadan. BMJ. (2010) 340:1407-11. doi: 10.1136/bmj.c3053

70. Farid D, Rosenberg E, Bartlett G. Importance of education in managing type 2 diabetes during Ramadan. Canadian Family Physician. (2014) 60:508-10.

71. Khaled MB, Menadi N, Boumediene A, Ktob A, Halfaoui S, Boukhatmi F. Rôle de l'éducation nutritionnelle dans la prise en charge du diabétique de type 2 pendant le Ramadan. Diabetes \& Metab. (2013) 39:A70. doi: 10.1016/S1262-3636(13)71914-1

72. Zainudin SB, AlOzairi E. IDF-DAR 2021 Practical Guidelines-Pre-Ramadan Assessment and Education. Available online at: https://www.researchgate. net/profile/Sueziani-Binte-Zainudin/publication/350625236_IDF-DAR_ 2021_Practical_Guidelines_-_Pre-Ramadan_Assessment_and_Education_ CHAPTER_7/links/606a6fe492851c91b1a2c80e/IDF-DAR-2021-PracticalGuidelines-Pre-Ramadan-Assessment-and-Education-CHAPTER-7.pdf (accessed June 30, 2021).

73. Babineaux SM, Toaima D, Boye KS, Zagar A, Tahbaz A, Jabbar A, et al. Multicountry retrospective observational study of the management and outcomes of patients with Type 2 diabetes during Rama-dan in 2010 (CREED). Diabet Med. (2015) 32:819-28. doi: 10.1111/dme.12685

74. El-Ghomari H. Consensus on diabetes treatment during Ramadan. Pra Diabetes Inter. (1998) 15:S8-9. doi: 10.1002/pdi.1960150908

75. Al-Arouj M, Bouguerrra R, Buse J, Hafez S, Hassanein M, Ibrahim MA, et al. Recommendations for management of diabetes during Ramadan. Diabetes Care. (2005) 28:2305-11. doi: 10.2337/diacare.28.9.2305

76. Al-Arouj M, Assaad-Khalil S, Buse J, Fahdil I, Fahmy M, Hafez S, et al. Recommendations for management of diabetes during Ramadan-update 2010. Diabetes Care. (2010) 33:1895-902. doi: 10.2337/dc10-0896

77. Ibrahim M, Abu Al Magd M, Annabi FA, Assaad-Khalil S, Ba-Essa E, Fahdil I, et al. Recommendations for management of diabetes during Ramadan: update 2015. BMJ Open Diabetes Res Care. (2015) 3:1-9. doi: 10.1136/bmjdrc-2015-000108

78. Ibrahim M, Davies MJ, Ahmad E, Annabi FA, Eckel RH, Ba-Essa EM, et al. Recommendations for management of diabetes during Ramadan: update 2020, applying the principles of the ADA/ EASD consensus. BMJ Open Diabetes Res Care. (2020) 8:1-14. doi: 10.1136/bmjdrc-2020-001248

79. Hassanein M, Al-Arouj M, Ben-Nakhi A, Jabbar A, Hanif W, Al-Madan A. Diabetes and Ramadan: Pratical Guidelines. Belgium: International Diabetes Federation and the DAR International Alliance (2016). 143p.

80. Hassanein M, Afandi B, Ahmedani MY, Alamoudi RM, Alawadi F, Bajaj HS, et al. Diabetes and Ramadan: Pratical guidelines 2021. Belgium: International Diabetes Federation and the DAR International Alliance (2021). 330p.

81. Pathan M, Sahay RK, Zargar AH, Raza SA, Azad Khan AK, Ganie MA, et al. South Asian Consensus Guideline: use of insulin in diabetes during Ramadan. Indian J Endocr Metab. (2012) 16:499-502. doi: 10.4103/2230-8210.97992

Conflict of Interest: The authors declare that the research was conducted in the absence of any commercial or financial relationships that could be construed as a potential conflict of interest.

Publisher's Note: All claims expressed in this article are solely those of the authors and do not necessarily represent those of their affiliated organizations, or those of the publisher, the editors and the reviewers. Any product that may be evaluated in this article, or claim that may be made by its manufacturer, is not guaranteed or endorsed by the publisher.

Copyright (๑ 2022 Bencharif, Sersar, Bentaleb, Boutata and Benabbas. This is an open-access article distributed under the terms of the Creative Commons Attribution License (CC BY). The use, distribution or reproduction in other forums is permitted, provided the original author(s) and the copyright owner $(s)$ are credited and that the original publication in this journal is cited, in accordance with accepted academic practice. No use, distribution or reproduction is permitted which does not comply with these terms. 